\title{
Stem borer insects on Hopea odorata in Bogor, West Java, Indonesia
}

\author{
NOOR FARIKHAH HANEDA`, MULYA FURQAN, MOHAMAD SUHERI \\ Department of Silviculture, Faculty of Forestry and Environment, Institut Pertanian Bogor. Jl. Ulin, IPB University Darmaga Campus, Bogor 16680, \\ West Java, Indonesia. Tel.: +62-251-8626806, Fax.: +62-251-8626886, •email: nhaneda @ apps.ipb.ac.id
}

Manuscript received: 30 July 2020. Revision accepted: 21 October 2020.

\begin{abstract}
Haneda NF, Furqan M, Suheri M. 2020. Stem borer insects on Hopea odorata in Bogor, West Java, Indonesia. Biodiversitas 21: 5308-5316. Hopea odorata Roxb. locally known as "merawan", is a dipterocarp species that has the potentials to be developed for plantation forestry. Nonetheless, anecdotal evidence in Bogor, West Java, Indonesia, suggested that the trees suffered serious attacks caused by stem borer insects, causing defoliation of the crown and leading to stunted growth and death. This phenomenon suggests a more systematic investigation. The objectives of this research were: (i) to identify the species of stem borer which attacked $H$. odorata; (ii) to investigate the types and forms of the damage of $H$. odorata tree due to stem borer attack; and (iii) to study the effects of stem borer attack on the tree and wood of $H$. odorata. The results showed that all species of stem borer insects belong to Coleoptera, namely as Xyleborus perforans (Scolytidae), Xyleborinus perexiguus (Scolytidae), Platypus parallelus (Platypodidae), Belionota prasina (Buprestidae), Curculionid beetle, and Tenebrionid beetle. The number of boring holes on a single tree was 1932 holes, of which $98.6 \%$ caused by ambrosia beetles: Xyleborus perforans (1426 holes, 73.8\%), Xyleborinus perexiguus (457 holes, 23.7\%), and Platypus parallelus ( 21 holes, $1.1 \%$ ). The length of boring tunnel at cross-section ranged between $2-35 \mathrm{~cm}$ and at longitudinal section ranged between 4-6 cm. The number of boring holes decreased along with the increasing height of tree stem. The patterns of boring tunnel at stem cross-section were branching (X. perforans, $P$. parallelus); encircled (X. perforans), black stains along their wall (X. perexiguus, X. perforans, P. parallelus).
\end{abstract}

Keywords: Ambrosia beetle, Coleoptera, Hopea odorata, Xyleborus, Scolytidae

\section{INTRODUCTION}

Dipterocarpaceae is one of the important plant families which comprises several commercial tree species. The members of this family constitute the dominant component of plant communities in tropical and subtropical forests. Several species are popular due to their timber quality, such as Dipterocarpus, Hopea, and Shorea. There are some advantages of Dipterocarpaceae timber for building construction, ship-building, railway sleepers, and plywood (Jha and Sen-Sarma 2008).

As we know, the population of dipterocarp trees in natural forests is declining. However, the production of Dipterocarpaceae wood is useful for various products such as construction wood. Therefore, the planning of forest plantations of dipterocarp trees becomes a solution for demand for timber resources. One of dipterocarp species that has the potential to be developed for timber plantation is Hopea odorata Roxb, or locally known as merawan. This species is known to have rapid growth and high survival (Junaedi 2012). According to Soerinegara and Lemmens (1994), the survival rate is almost $100 \%$ with a diameter of $53 \mathrm{~cm}$ at the age of 25 years.

Nevertheless, the development of Dipterocarpaceae plantations consisting of only a single species is vulnerable to pests and diseases. In developing forest plantation, pest frequently becomes one of major problems for management. Tree species from Dipterocarpus, Hopea, dan Shorea have a broad spectrum of pests, which attack the seeds, seedlings, fruits, timber, and forest stands (Jha and Sen-Sarma 2008). In seedling phases in the nursery, pests generally attack Dipterocarpaceae in the form of caterpillars, bag worm, and termites, while in planting phase in the field, pests attack in the form of fruit tumors, shoot and branch borer, sucker liquid stems, termites, Scarabaeidae beetles, fruit or seed pests, and wildlife (Wahyudi et al. 2014). For example, the family member of Dipterocarpaceae from the Shorea group was found being infected with termites, fungi, leaf spots, and stem cancer (Triwibowo et al. 2014). Other studies found in Kalampangan Forest found Dipterocarpaceae trees were attacked by pathogens, such as stem cancer, tumor stem, rotten stem, leaf blight, leaf rust, leaf patches, leaf holes, and resinosis (Firdara et al. 2009). Among them, one of the most dangerous pests in forest plantation is stem borers (Duan et al. 2017)

Some stem borers which attack forestry plantation are from Coleoptera groups, including ambrosia and bark beetles. Ambrosia beetles cause a decrease in the productivity and quality of wood when harvested. It is suspected that the insect serves as a vector of several pathogens in forest plantations, such as Acacia sp. and Eucalyptus sp. Pest management by applying intensive silvicultural system is an alternative to reduce beetle populations in natural and industrial timber plantations (Gitau et al. 2013). For instance, in Sweden, many fallen trees caused by storm became the hosts for ambrosia and bark beetles and spread to other standing and healthy trees. Then, the solution was to regularly cut down the trees that have collapsed due to storms in order to reduce the source 
of inoculum for the spread of beetle attacks (Kärvemo et al. 2014). Horizontal phytosanitary processes have been suggested by the European and Mediterranean Plant Protection Organization (EPPO) as an activity to prevent the spread of ambrosia and bark beetles in international timber trade (Grousset et al. 2020)

Stem borer insects are also indicated to attack $H$. odorata. An anecdotal case was found in $H$. odorata trees grown around the Faculty of Forestry and Environment, IPB University, Bogor, West Java Indonesia. The trees suffered considerably serious attack caused by stem borer insects which had caused crown defoliation, leading to stunted growth, and death. The objectives of this research were (1) to identify the species of stem borer which attacked $H$. odorata in that area; (2) to investigate the types and forms of the damage of $H$. odorata tree due to stem borer attack; and (3) to study the effects of stem borer attack on the tree and wood of $H$. odorata.

\section{MATERIALS AND METHODS}

\section{Observation of stem damage and insect collection}

Hopea odorata was planted in Faculty of Forestry and Environment, IPB University, Bogor, Indonesia. There were $11 \mathrm{H}$. odorata trees. The age of plants is around 10 years old with a height of 10.5 meters and a diameter of $16.5 \mathrm{~cm}$. The origin of those seedlings was from Haurbentes Research Forest, Bogor, Indonesia. The research study was conducted in 3 months.

The form of damage was studied by cutting down $H$. odorata tree which had been dead and contained boring holes. Then, the stem was cut and divided into several segments with a length of around $1 \mathrm{~m}$ for each segment except the last segment (the upper end) from which the length was only $0.5 \mathrm{~m}$. There were 10 segments with a length of $1 \mathrm{~m}$ and the other of $0.5 \mathrm{~m}$. This implies that the boring holes were scattered from ground surface up to over $10.5 \mathrm{~m}$ height. The calculation of the boring holes, the collection of insects, and the observation of the pattern of the boring holes were then conducted per segment.

The boring holes calculation was started from segment I which constituted the lowest part of tree to the segment XI (part of the uppermost end of the tree being attacked). To facilitate the calculation of the boring holes, one segment per meter was divided further into shorter segments $( \pm 10$ $\mathrm{cm}$ ), by encircling each segment with white thread. Afterward, needles with rounded handles were inserted into boring holes. The number of boring holes was equal to the number of needles being inserted.

Studying the pattern of insect boring holes was conducted by cutting the segments crosswise at the boring holes. Such cross-cutting was conducted on several boring holes with various diameters. The insect collection was conducted together during studying insects' boring holes pattern. Some insects were found when the wood segments were cut crosswise. Those insects were put inside insect collection bottles and were separated based on the species of insect. The diameter of the boring holes was measured in each segment. Because of the large number of boring holes, the diameter of boring holes $(\mathrm{x})$ was classified into five groups: diameter $0<x \leq 1 \mathrm{~mm}$, diameter $1<\mathrm{x} \leq 2 \mathrm{~mm}$, diameter $2<\mathrm{x} \leq 3 \mathrm{~mm}$, diameter $3<\mathrm{x} \leq 4 \mathrm{~mm}$, and diameter $4<\mathrm{x} \leq 5 \mathrm{~mm}$.

\section{Identification of insects.}

Identification was intended to determine the species of stem borer insects that attacked $H$. odorata trees. The identification was conducted by using determination key and combining two or more identification procedures, guided by the staff of Zoology Laboratory, Division of Entomology, Indonesian Institute of Sciences (LIPI), Cibinong. The guidance book used for identification was An Introduction to The Study of Insects (Borror et al. 1992).

\section{Data analysis.}

The data were derived by counting numbers of boring holes, and were analyzed by using linear regression model consisting of one independent variable $(x)$, namely number of boring holes; and dependent variable (y), namely tree stem height. The data were processed to obtain the values number of boring holes, the length of boring holes, and the percentage of boring holes. The data was aimed to identify the relationship between the number of boring holes on tree and the stem height.

Formulas that were used for calculating the total number, length, and percentage of boring holes, are as follows:

\section{Total boring holes}

The boring holes total $\left(\mathrm{G}_{\mathrm{x}}\right)$ constitutes the number of boring holes for each diameter on whole segments.

$$
G_{X}=\sum_{i=1}^{n} G_{i}
$$

Where:

$G_{\mathrm{x}}$ : Number of boring holes for each diameter on whole segments

$G_{i}$ : Number of boring holes for each diameter on $i^{\text {th }}$ segment.

\section{Length of boring holes}

Length of boring holes (L) is the sum or total of all branches of boring holes.

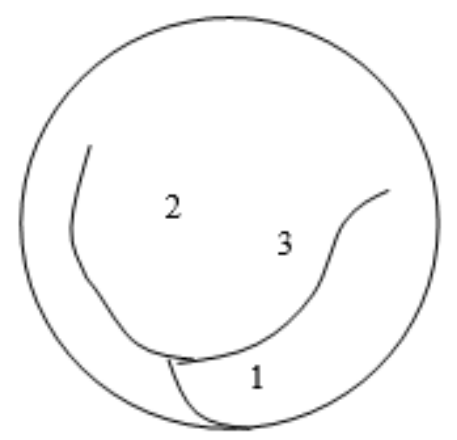

(L = length $1+$ length $2+$ length 3 ) 


\section{Percentage of boring holes}

Percentage of boring holes $(\mathrm{P})$ constitutes the ratio of the number of boring holes for each diameter on whole segments to the number of boring holes for all sizes on all segments.

$$
P=\frac{G_{X}}{N} \times 100 \%
$$

Where :

$\mathrm{P}$ : Percentage of boring holes (\%)

$\mathrm{G}_{\mathrm{x}}$ : Number of boring holes for each diameter on all segments

$\mathrm{N}$ : Number of boring holes for all sizes on all segments

\section{RESULTS AND DISCUSSION}

\section{Species of insects attacking Hopea odorata trees}

Table 1 shows insect identification result, which indicates there were six of the 12 pest insects that were found during the study categorized as stem borer and belong to Coleoptera order. The insects from the orders of Thysanoptera and Dermaptera were not categorized as stem borers.

Thysanoptera or thrips are insects with spinose wings. Some of the insects have wings, while others do not. Thrips have sucking type mouth and exhibited simple metamorphosis. The bodies had very small size, about $<6$ $\mathrm{mm}$. These insects ate various parts of plants, such as wood, fruit, leaves, and fungi (Gibb 2015). The observation results showed that Thysanoptera insects have very small, flat and slim bodies with body length of $\pm 1 \mathrm{~mm}$, body width of $<1 \mathrm{~mm}$, and white, yellowish, or clear body color with red and orange dot or line. The thrips that had been observed were predicted from suborder Tubulifera, which places eggs inside crevices or under barks. According to Sangyeot (2016), this insect is generally known as an important pest that influences agricultural productivity, nonetheless not many people knew that some species of thrips are predators of mites and small lice that have potential for biological control.

Dermaptera is insects that have elongated, slim and slightly flattened bodies. The wings are folded when the insects were resting, and this insect exhibited simple metamorphosis. The bodies had sizes ranging from small to medium $(4-26 \mathrm{~mm})$. This order has biting and chewing type mouth and long antennae; lived in bark part and eats decay materials (Coulson and Witter 1984). The observation results showed that Dermaptera insect had small size with body length of $\pm 5 \mathrm{~mm}$, body width of \pm 2 $\mathrm{mm}$, and in their behind part, there were tweezers with blackish color.

Most Dermaptera was active at night and hide during day time in crevices and inside small holes under bark (Alford 2012). Many Dermapteras acts as pest predators (Alford 2012). As well as Thysanoptera, the Dermaptera found in this research was strongly predicted as predator. This study is most focused on Coleoptera insects which act as stem borer insects

\section{Discussion}

Species of stem borer insects attacked $H$. odorata trees in this study are further described as follows.

\section{Xyleborus perforans}

The observation results showed that imago of Xyleborus perforans had small size with the body length of $\pm 2.5 \mathrm{~mm}$, body width of $\pm 1.5 \mathrm{~mm}$, and reddish-brown color (Figure 1.A). According to O'donnell (2014), Xyleborus spp. is categorized as wood borer (heartwood and sapwood). It is also included 'ambrosia' beetle (Harrington et al. 2011). This insect has natural enemies from the aves group. Research by Fullard et al. (2010) identified $75.7 \%$ of the feces on the bird's nest Aerodramus sawtelli found $X$ perforation fragments of $75.7 \%$ of all examples. This is the basis that this species of wallet bird may be a managing agent for pinhole borer beetles.

Symptoms of Xyleborus' attack were identified as boring holes with diameter of $\pm 2 \mathrm{~mm}$. From the boring holes, there was fine-grained powder. Tree's stems which were severely attacked would appear dirty, due to the presence of brown wet dirt, which was a mixture of boring powder, fungi, insect feces and tree juices. Inside the stem, the beetle would create constructed perpendicular to the trunk, in a horizontal plane, and consists of a primary entrance tunnel that, over time, branches into 2-5 secondary tunnels (Brar et al. 2013). According to Beaver et al. (2014), they made a gallery system consisting of irregularly branched tunnels, usually in one horizontal plane, but sometimes spreading in three dimensions and without brood chambers.

This species sometimes attacks fragile or injured timber, and becomes a minor pest, but it is always a secondary attack (Browne 1968). Because of its plentiful, this species can become an important pest in decreasing the quality of newly harvested wooden. In Thailand, this species can be found in rubberwood (Kangkamanee et al. 2011). This species is also found in stressed mango trees (Sittichaya 2012). It was reported in a study by Misra et al. (2020) that pomegranate shot hole borer (X. perforans) is a transmission medium for pathogenic fungi wilt on commodity pomegranate trees in India.

Table 1. Species of insects found in the stems of Hopea odorata trees

\begin{tabular}{|c|c|c|}
\hline Species & Family & Remark \\
\hline Xyleborus perforans & Scolytidae* & Borer \\
\hline Xyleborinus perexiguus & Scolytidae* & Borer \\
\hline Platypus parallelus & Platypodidae $*$ & Borer \\
\hline Belionota prasina & Buprestidae * & Borer \\
\hline Anomala pagana & Scarabaeidae * & Defoliator \\
\hline- & Curculionidae $*$ & Borer \\
\hline- & Tenebrionidae * & Borer \\
\hline- & Thripidae $* *$ & Predator \\
\hline- & Thripidae $* *$ & Predator \\
\hline - & Thripidae $* *$ & Predator \\
\hline - & Heterothripidae $* *$ & Predator \\
\hline- & Forficulidae $* * *$ & Predator \\
\hline
\end{tabular}

Note: *: Order Coleoptera, **: Order Thysanoptera, ***: Order Dermaptera 


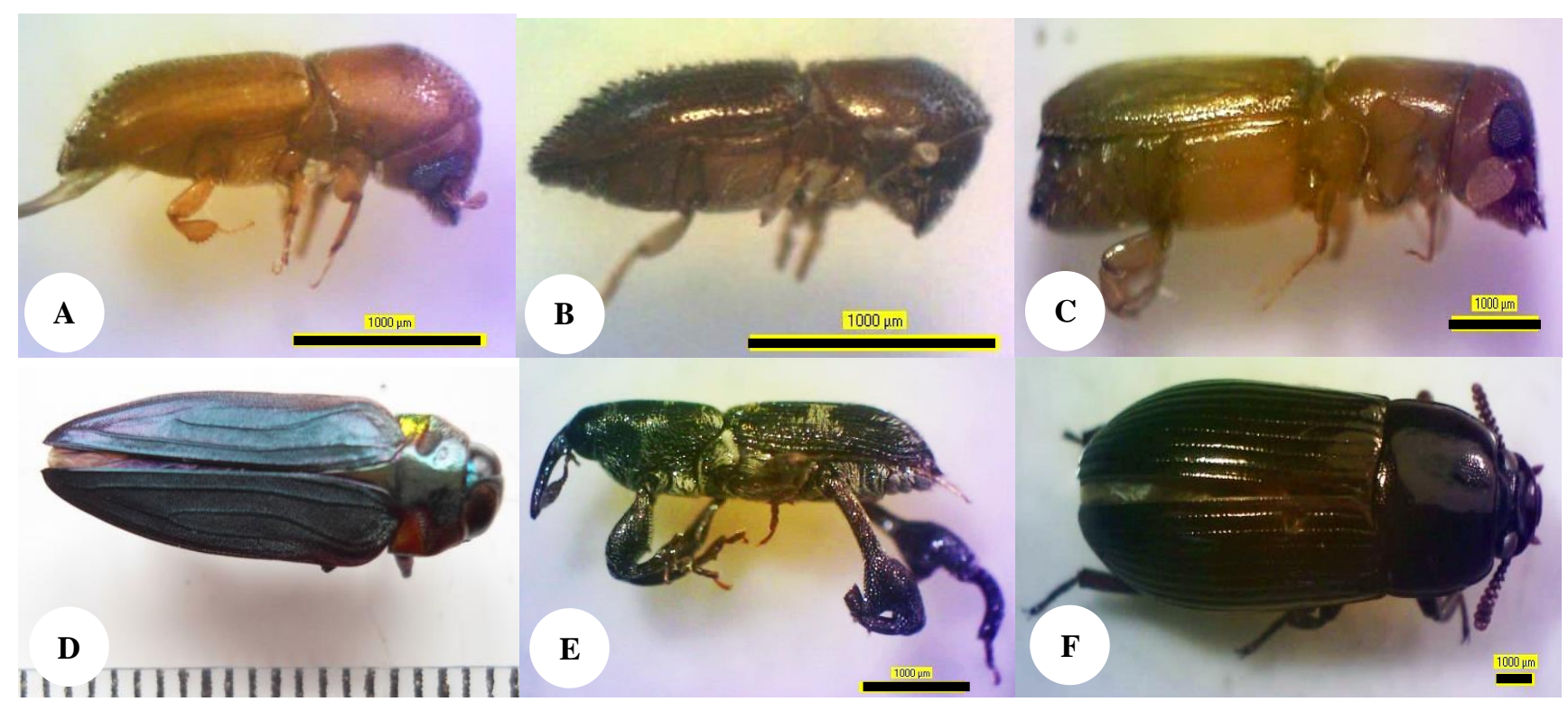

Figure 1. Imago of stem borer species: A. Xyleborus perforans, B. Xyleborinus perexiguus, C. Platypus parallelus, D. Belionota prasina, E. Curculionid beetle, F. Tenebrionid beetle. Bar $=1000$ um

\section{Xyleborinus perexiguus}

Similar to Xyleborus perforans, this species was categorized as 'ambrosia' beetle. When boring into the wood, the female beetles carry ambrosia fungi into the boring tunnel as food for the larvae and imago. Based on the observation results, the shape of imago of Xyleborinus perexiguus was almost similar to Xyleborus perforans, due to their close kinship within one family. However, this species had smaller size, with its body length of $\pm 1.5 \mathrm{~mm}$, its body width of $\pm 1 \mathrm{~mm}$, and blackish-brown color (Figure 1.B).

This small and slender oriental ambrosia beetle appears naturally from Sri Lanka spread Southeast Asia, and in Sulawesi Indonesia (Beaver 2015). Reported from data species from West Africa (Gabon), Xyleborinus pexiguus is one of the most numerous of scolytine collected during intensive insect traps from January till March 1999 (Basset et al. 2001). According to Gohli et al. (2016), the spreading of the ambrosia beetle genus Xyleborus, in addition, has been distributed by the activity of sending wood material by humans, however, several million years ago it was proven that the groups of beetles were genetically present in most of their distribution range so it is no astonishing that this species is founded in every tropical and subtropical zone.

This type of beetle tends not to be selectively in using a host tree (Browne 1961). Data from Panama shows that this species is predominantly found in the canopy, but unlike $X$. crasssiusculus this type does not indicate a height alternative. This species is not considered an aggressive type (Browne 1961), but all ambrosia beetles have the potential to spread pathogenic fungi to host plants. According to McPherson (2013) that ambrosia and bark beetles penetrate the trunk of the Quercus agrifolia tree by bringing along the pathogenic fungus Phytophthora ramorum, caused the rapid death of many trees in California and Oregon. However, research on the aposymbiotic interaction of Fusarium euwallaceae fungi with ambrosia beetles on avocado trees indicate that the spread of pathogenic fungi is not far from bore-hole beetles (Freman et al. 2019).

\section{Platypus parallelus}

Observation results showed that imago of Platypus parallelus had small size with its body length of $\pm 5 \mathrm{~mm}$, body's width of $\pm 2 \mathrm{~mm}$, and blackish color (Figure 1.C). According to Tarno et al. (2014), They had body's length ca. $4 \mathrm{~mm}$, with clubbed antenna, round and convex eyes, and brown body. They are usually referred to needle hole borer. These beetles are wood borer and they bore live trees, but seldom attack healthy trees. These beetle attack broadleaved trees and conifer. Euplatypus parallelus (F.) (Coleoptera: Curculionidae) is one of the most invasive species of all the Platypodinae. It penetrates the xylem and oviposits in its host trees thereby weakening the trunk causing them to break under extreme conditions (Lei et al. 2020). The subfamily Platypodinae encompasses more than one thousand species of ambrosia beetles, but most are tropical kind, and the genus platypus is the only Palaearctic distributed. Platypus spp. mostly attacked broad leaves (Ploetz et al. 2013). P. parallelus is known to attack living trees that have been damaged whether by fire, drought, pathogens, or other causes. (Beaver 2013).

All Platypus spp. are ambrosia beetle. P. parallelus, originating from south and central America, now exist in almost all oriental regions, and in some parts of Wallacea and new guinea. The actual source and original import site is unknown, but has been widespread in Sri Lanka since 1970s and habitat in Malaysia, Indonesia, and Thailand from the 1980s (Beaver 2013). The process of spreading ambrosia beetles groups is by natural processes or through human hands, but they will usually develop in areas with climatic conditions appropriate for reproduction and development (Rassati et al. 2016). This species prefers 
areas with a steady, warm, rainy climate, which indicates that tropical and subtropical areas would be ideal areas (Tang et al. 2018). The larva and the adult eat the 'ambrosia fungi which grow on the wall of the boring tunnel. This beetle itself does not eat the wood. Platypus species usually make boring tunnel with greater area in the sapwood and they are able to extend the tunnel to the heartwood. Most Platypus is pest of round wood, or newly sawn timber. However, several of them attack damage tree stand or unhealthy stand. In several cases, they even attack healthy trees (Speight dan Wylie 2000). Additionally, under favorable circumstances, ambrosia beetles may change their behavior and start attacking healthy trees (Ploetz et al. 2013), which represents an additional concern to forest keepers. In the majority of studies, the attacks by $P$. parrallelus appeared to be secondary on trees that have already been damaged by pathogens or other causes, rather than primary attacks on healthy trees. However, the primary attacks can happen ( Bumrungsri et al. 2008). They are usually closely associated with fungi, which may be pathogenic causing tree mortality( Gümüş \& Ergün 2015). This species is most serious pest and most abundant species of platypodine in some areas at lower altitudes (Beaver 2016).

\section{Belionota prasina}

The observation results showed that imago of Belionota prasina had small size with its body length of $\pm 20 \mathrm{~mm}$, its body width of $\pm 7 \mathrm{~mm}$, and bluish dark green color, while the larva was yellowish-white (Figure 1.D). According to Ramasamy (2018), the observation results of grown insects B. prasina have a dark greenish-blue color with a size about 21-28 $\mathrm{mm}$. The larvae have a yellowish-white color with a body-sized 9-50 mm. Many larvae of Belionota only bored phloem tissue. The following description explains the life cycle variation of this phloem borer, whose heads are flattened. In general, this beetle prefers weak and damaged host. The imago places the eggs on the surface or cracks of the host's bark. Afterward, the larvae bore into the phloem, where it creates oval chamber with crosswise direction. Pupation occurs in that chamber or sometimes inside the xylem. After that, the imago emerges and bores until reaching the outer surface (Coulson and Witter 1984).

Adult beetle never enters again into the host tree after it went out. Therefore, only larvae chambers exist in the inner part of the bark. This larva never goes out because there are no holes in the surface. Therefore, the arching larvae's chamber is always filled with the larvae of this species (Anderson 1960). Australian Buprestidae, popularly known as 'jewel beetles' has many host-plant as Mangifera indica, Ceiba pentandra, Delonix regia, and Casuarina sp. (Bellamy et al. 2013). According to Schnepp et al (2020), B. prasina population in Florida (Unites State) is genetically diverse and may only be attracted to dead or declining trees.

\section{Curculionidae beetle.}

The Curculionidae family including the Superfamily Curculionoidaea is a beetle of wood, bark, and ambrosia. This superfamily is the most various species beetles, with more than 60,000 species described (Oberprieler et al. 2007). Four-fifths of all beetles are in the Curculionidae family. Curculionoids are spreading throughout the world, found in all types of plant vegetation (Sauvard et al. 2010). The beetle of family Curculionidae is also referred to kumbang moncong (snout beetle) (Husaeni et al. 2006). The observation results showed that the imago sizes of this species were as follows: its body length $\pm 4 \mathrm{~mm}$, and its body width $\pm 2,5 \mathrm{~mm}$, while the color was black (Figure 1.E).

All snout beetles (except several of them which occurred in ant nests), are plant eaters and many of them are serious pests. Several species of them lived in barks or dead stems. Nearly all plant parts could be attacked, ranging from the root to all parts above the roots. During its life cycle, the bark beetle reproduces in logs from which it flies to host-trees to dig feeding galleries and overwinter (Ruano et al. 2010). According to Huda et al. (2019), snout beetle constitutes one of the family of order Coleoptera which becomes stem borer in larvae stage. Based on research by Pineda et al. (2014), beetle type of the Curculionidae family known as bark beetle on host plants (Pinus greggii). The results of scanning trees on postoutbreak host plants show that the beetles were found on all parts of the trees sampled.

Some species, mature and larvae of Curculionoidae are pohytophagous. The larvae are mostly endophytic or underground. The beetles consume all variety of plants, attacking all parts. Many species are important pests for agriculture and forestry (Sauvard et al. 2010). Several species of snout beetles bore stems, mainly during larval stage (Kalshoven 1981). Its eggs are usually prepared inside the plant tissue. In the beginning, the female insect makes hole with its snout (long and sharp mouth). Afterward, the eggs were inserted into the hole which has been made, by using pygidium which resembles ovipositor (apparatus for placement of the eggs) (Pracaya 2007).

\section{Tenebrionidae beetle}

Tenebrionidae contains around 20,000 species and 2,300 genera belonging and settled in tropical habitats (Beutel and Leschen 2005). In general, these insects become pests that consume plant material, including rotting material, wood, leaf litters, pollen, mushrooms, and algae. Some temporary decomposers, some of them predators, especially wood borer beetles (Soldati and Soldati 2003). Some studies note that tenebrionid species, dark beetles may be the basis in important processes of ecosystem function such as environmental quality indicators, because their existence indicated that the area in question is relatively undisturbed but the majority of these insects are decomposers (Hwayyiz et al. 2016).

The observation results showed that imago sizes were as follows: its body length was $\pm 12 \mathrm{~mm}$, its body width was \pm $5 \mathrm{~mm}$, while the color was blackish brown (Figure 1.F). These beetles live in darkness. Tenebrionidae beetle is in varying. Most of them have brownish or black color. Several species have rough bodies and slightly resemble wood barks. It is very common to find them under loose bark. Most 
Tenebrionidae have wide range of consumption preferences (Brygadyrenko and Nazimov 2015). Other insects found in the sampled trees were Thysanoptera and Dermaptera although both are considered as predator than stem borer.

Thysanoptera or thrips are insects with spinose wings. Thrips have sucking-type mouth and exhibit simple metamorphosis. The bodies have very small size, about $<6$ $\mathrm{mm}$. These insects eat various parts of plants, such as wood, fruit, leaves and fungi (Gibb 2015). The observation results showed that Thysanoptera insects have very small, flat and slim bodies with body length of $\pm 1 \mathrm{~mm}$, and width of $<1 \mathrm{~mm}$ and had white, yellowish, or clear body color with red and orange dot or line. The thrips that had been observed were predicted from suborder Tubulifera, which places eggs inside crevices or under barks. According to Sangyeot (2016), this insect is generally known as an important pest affects agricultural productivity, nonetheless some species of thrips are predators of mites and small lice that have potential for biological control.

Dermaptera is insects that have elongated, slim, and slightly flattened bodies. The wings are folded when the insects are resting, and these insects exhibit simple metamorphosis. They have varying body size, from small to medium (4-26 mm). This order has biting and chewing type mouth and long antennae; lives in bark part and eats decay materials (Coulson and Witter 1984). The observation results showed that Dermaptera insect had small size with body length of $\pm 5 \mathrm{~mm}$, body width of $\pm 2 \mathrm{~mm}$, and in their behind part, there were tweezers with blackish color.

Most Dermaptera are active at night and hide during daytime in crevices and inside small holes under bark (Alford 2012). Many Dermapteras acts as pest predators (Alford 2012). As well as Thysanoptera, the Dermaptera found in this research was strongly predicted as predator.

\section{Number and length of boring holes}

The result of boring holes calculation is presented in Table 2, which shows that the number of boring holes being found was 1932 holes. About $97.5 \%$ of the holes were created by Scolytidae beetles: Xyleborus perforans (1426 holes, 73.8\%); Xyleborinus perexiguus (457 holes, $23.7 \%$ ), while $2.5 \%$ were created by other beetles. Tenebrionidae beetle created only 3 holes $(0.1 \%)$. Average number of boring holes was 188 holes per stem segment with length of $1 \mathrm{~m}$, whereas the length of boring tunnel on cross section ranging between $2-35 \mathrm{~cm}$ and $4-6 \mathrm{~cm}$ in the longitudinal section of the stem. The effect indicated that the dominant attack on the rosemary tree is the group of ambrosia beetles. The kind of ambrosia beetles that are considered to be polyphagous has a large uterine tolerance so that in some cases it is dominantly found to attack plantation and forestry. The results of this research are in line with Flechtmann et al. (2001) that the results of the trap method research on the strength of Eucalyptus and Pinus taeda in Brazil, so the dominant type has been found is the type of Xyleborinus beetles. The trap results of the two ecosystems are not significantly different so it can be concluded that the known type of ambrosia beetles has a large host-plant (polyphagous).

Figure 2 presents the result of regression analysis to investigate the relationship between the number of boring holes and tree stem height. From the equation resulted from the regression, it can be seen that there is a negative correlation, implying that the number of boring holes decreased with increasing height of the tree stem. According to Kuswana (2003), this phenomenon is caused by several factors, including: (i) the lowest part of the tree has greater diameters than the upper part, so that the room for insects' growth is larger; (ii) factors of temperature and humidity, in which in the lowest part of the tree stem has lower temperature and higher humidity than the upper part, making this condition supports the growth of ambrosia fungi and insects; (iii) habit of flying which is dominant at lower height (1-2 $\mathrm{m}$ above ground surface), causing attacks to be more frequent in the lowest part of the tree stem; (iv) density of undergrowth vegetation and tree crown could reduce the light intensity entering the lower part of the stand; (v) large amount of groundwater that affects the humidity of the lowest part of the stem. This is also supported in the research by Pineda et al. (2014) that the number of mature beetle individuals was significantly different among sections of the trunk $(H=1210, d f=5, p<0.05)$ in which more bark beetles were found at the trunk base and first two sections above the base than in the higher parts on the trees. No difference was found in total abundance of bark beetles among trees $(\mathrm{H}=15.2, \mathrm{df}=7, \mathrm{p}>0.05)$

Table 2. Number of boring holes found in tree stem of Hopea odorata

\begin{tabular}{|c|c|c|c|c|c|c|}
\hline \multirow{2}{*}{ Segment } & \multicolumn{5}{|c|}{ Diameter of boring holes (x) (mm) } & \multirow{2}{*}{$\sum$} \\
\hline & $0<x \leq 1$ & $1<x \leq 2$ & $\mathbf{2}<\mathrm{x} \leq \mathbf{3}$ & $3<x \leq 4$ & $4<x \leq 5$ & \\
\hline I & 56 & 154 & 1 & 5 & 0 & 216 \\
\hline II & 85 & 199 & 1 & 3 & 0 & 288 \\
\hline III & 78 & 192 & 2 & 3 & 0 & 275 \\
\hline IV & 77 & 157 & 1 & 2 & 0 & 237 \\
\hline $\mathrm{V}$ & 29 & 148 & 3 & 1 & 0 & 181 \\
\hline VI & 13 & 144 & 5 & 0 & 0 & 162 \\
\hline VII & 20 & 115 & 5 & 2 & 0 & 142 \\
\hline VIII & 21 & 124 & 0 & 2 & 1 & 148 \\
\hline IX & 27 & 99 & 3 & 1 & 0 & 130 \\
\hline $\mathrm{X}$ & 19 & 75 & 2 & 2 & 0 & 98 \\
\hline $\mathrm{XI} *$ & 32 & 19 & 2 & 0 & 2 & 55 \\
\hline$\sum$ & 457 & 1426 & 25 & 21 & 3 & 1932 \\
\hline$\%$ & 23.7 & 73.8 & 1.3 & 1.1 & 0.1 & - \\
\hline Species & $X$. perexiguus & X. perforans & Curculionid beetle & P. parallelus & Tenebrionid beetle & - \\
\hline
\end{tabular}



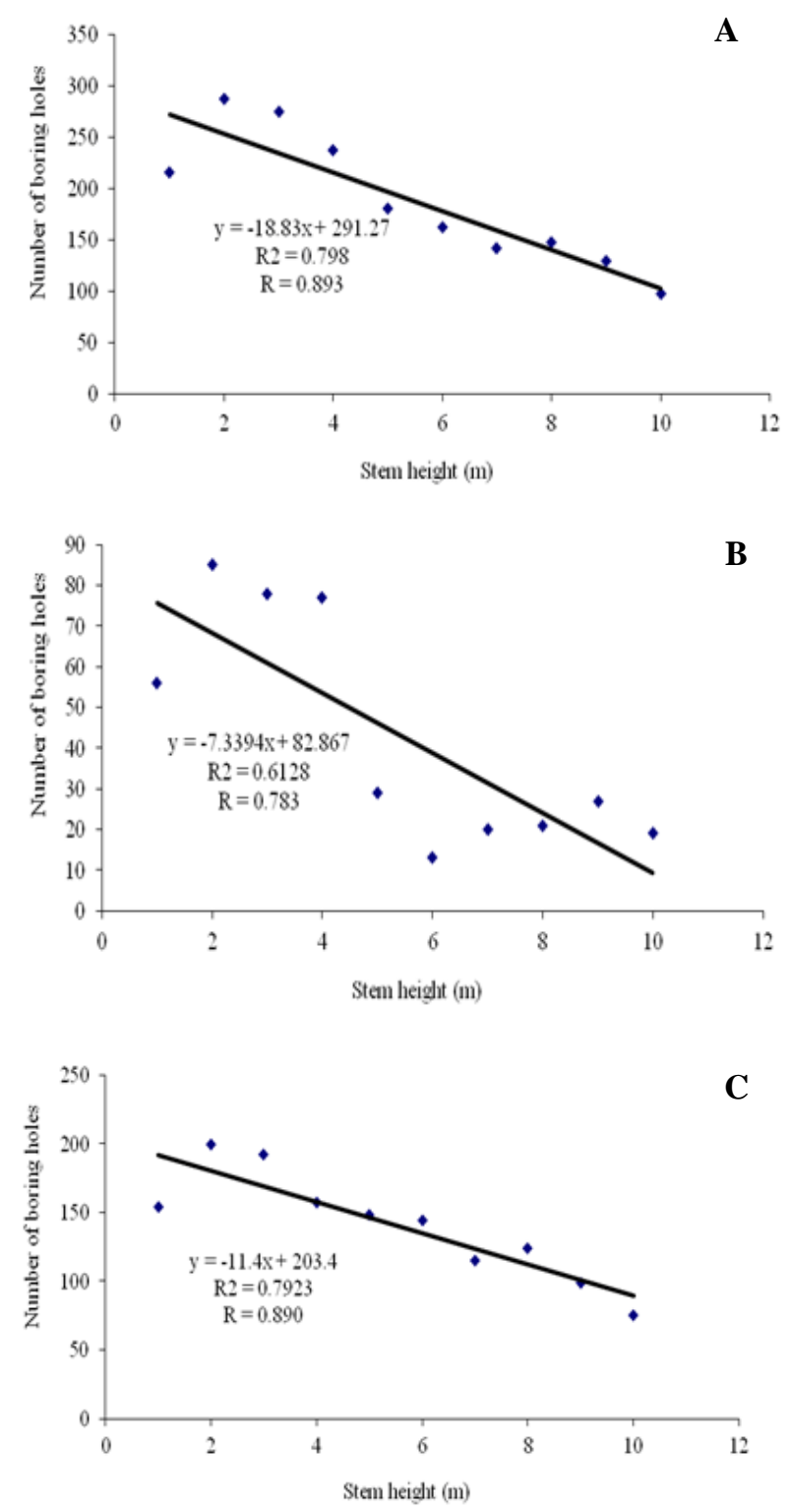

Figure 2. Relationship between the number of boring holes and the height of tree stem and size of boring hole diameter: A. All diameters; B. Diameter $0<x \leq 1 \mathrm{~mm}$; C. Diameter $1<x \leq 2 \mathrm{~mm}$

\section{Pattern of boring tunnel}

Figure 3 shows the general pattern of boring tunnels at stem cross section for each diameter of boring holes. From Figure 3 , it can be seen that boring holes with the diameters of $0<x \leq 1 \mathrm{~mm}, 1<x \leq 2 \mathrm{~mm}$, and $3<x \leq 4 \mathrm{~mm}$ possessed black stains along the boring tunnel. Such a black stain was probably caused by ambrosia fungi. Ambrosia fungi spoiled the wall of the boring hole and this was commonly referred to as 'pencil streak'. Bark and ambrosia beetle build channel or tunnel by biting and chewing the stems with the help of their short, thick, and strong mandible. When they are eating, these beetles harvest ambrosia mold spores on the walls of the tunnel by chewing them on the labrum in the horizontal movement of the maxilla
(Kirkendall et al. 2015). For boring holes with the diameters of $2<x \leq 3 \mathrm{~mm}$ and $4<x \leq 5$, the black stains were not found along the boring tunnel. The stems that had been decayed have a lower nitrogen content than the body of the beetle so that the association of beetles with ambrosia mushrooms is one of the fulfilment of nutrients (one of which is N) which affects their frequency (French \& Roeper 1975)

The shape of the insect, diameter of the boring holes, and characters of wood powder which was taken out of the boring holes are often used to identify the insect or damage level at genera or species level (Johnson 1958 referred in Coulson and Witter 1984), as well as the pattern of boring holes.

Therefore, it can be inferred that the boring holes with diameter of $0<x \leq 1 \mathrm{~mm}$ were made by Xyleborinus perexiguus, the boring holes with the diameters of $1<x \leq 2$ $\mathrm{mm}$ were made by Xyleborus perforans, the boring holes with diameters of $2<x \leq 3 \mathrm{~mm}$ were made by Curculionidae beetle, the boring holes with the diameters of $3<x \leq 4 \mathrm{~mm}$ were made by Platypus parallelus, and the boring holes with the diameters of $4<x \leq 5 \mathrm{~mm}$ were made by Tenebrionid beetle.

Figure 3 shows the patterns of boring tunnels at crosssection of the stem. Based on the observation results, this pattern was made by larvae of Belionota prasina. The larvae of Belionota prasina created the most severe damage on the wood. Boring tunnels where the larva nearly encircled the stem, was observed throughout cross-section. The larvae bored the wood at the sapwood or exactly below the bark. Boring holes had ellipse shape and formed depression into the wood and was completely filled with boring powder. The length of boring tunnel was $\pm 4 \mathrm{~cm}$ and the width was $\pm 1.5 \mathrm{~cm}$.

In summary, the species of stem borer insects at Hopea odorat in this study were Xyleborus perforans (Scolytidae), Xyleborinus perexiguus (Scolytidae), Platypus parallelus (Platypodidae), Belionota prasina (Buprestidae), Curculionidae beetle, and Tenebrionidae beetle. The number of boring holes was 1932 holes with an average of 188 holes per stem segment of $1 \mathrm{~m}$ length. The length of boring tunnel at cross section ranging between $2-35 \mathrm{~cm}$ and a longitudinal section ranged between $4-6 \mathrm{~cm}$. The number of boring holes decreased along with the increasing height of tree stem. There were $98.6 \%$ of boring holes caused by ambrosia beetles: Xyleborus perforans (1426 holes, $73.8 \%$ ), Xyleborinus perexiguus (457 holes, $23.7 \%$ ), and Platypus parallelus (21 holes, $1.1 \%$ ). The rest were caused by Curculionidae beetles ( 25 holes, $1.3 \%)$ and Tenebrionidae beetle ( 3 holes, $0.1 \%$ ). The pattern of boring tunnels at stem cross-section were as follows: boring tunnels with branching pattern (Xyleborus perforans, Platypus parallelus), encircling the stems (Xyleborus perforans), and several boring tunnels with black stains along their wall (Xyleborinus perexiguus, Xyleborus perforans; Platypus parallelus). The attack of stem borer insects had caused crown defoliation, tree death, and reduction of quality and quantity (volume) of the wood of Hopea odorata. 


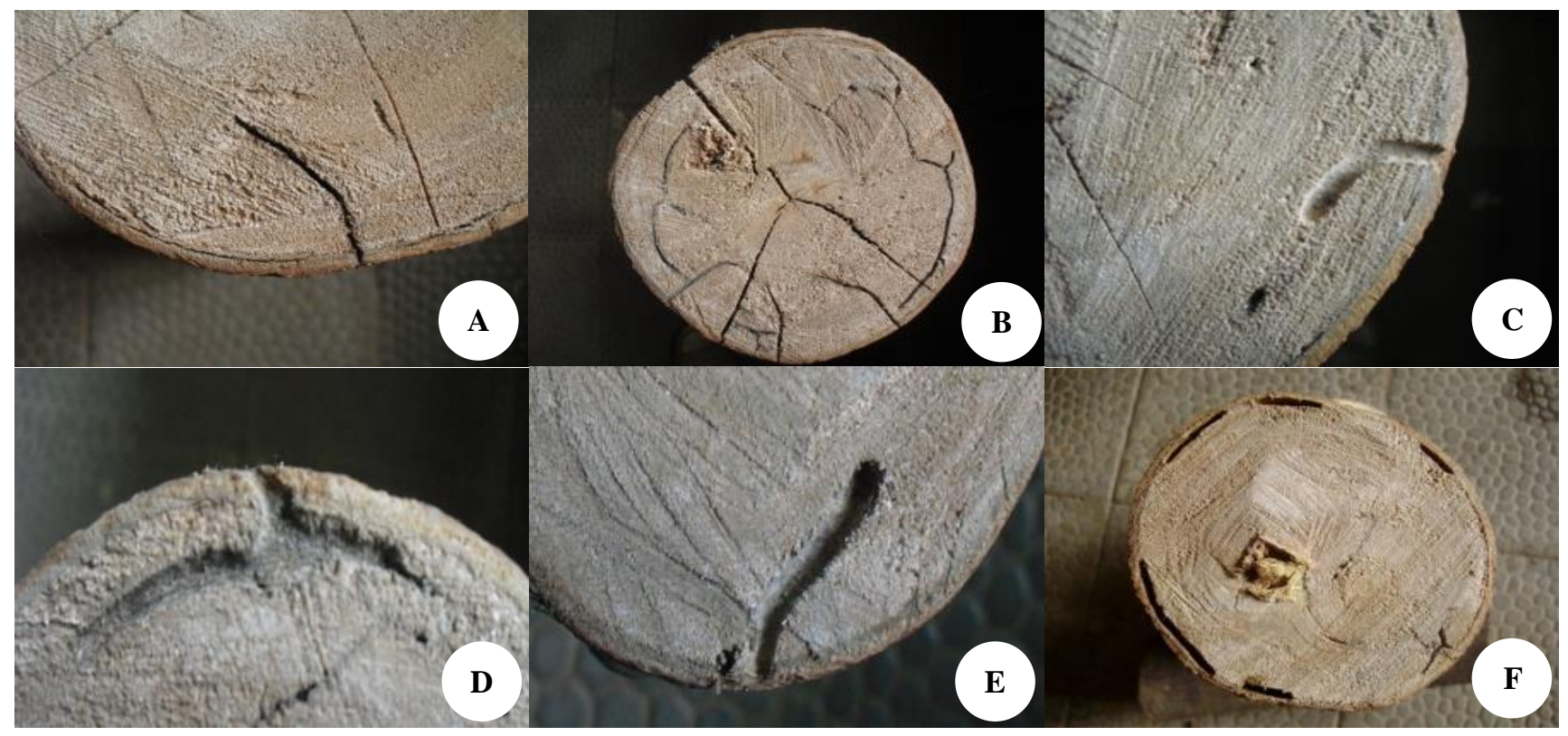

Figure 3. Patterns of boring tunnels at stem cross-section of each diameter: A. Diameter $0<x \leq 1 \mathrm{~mm}$; $\mathrm{B}$. Diameter $1<\mathrm{x} \leq 2 \mathrm{~mm}$; C. Diameter $2<\mathrm{x} \leq 3 \mathrm{~mm}$;D. Diameter $3<\mathrm{x} \leq 4 \mathrm{~mm}$; E. Diameter $4<\mathrm{x} \leq 5 \mathrm{~mm}$; and F) boring hole of Belionota prasina larvae under the bark

\section{REFERENCES}

Anderson RF. 1960. Forest and Shade Tree Entomology. John Wiley and Sons, Inc. New York

Alford DV. 2012. Pest of Ornamental Trees, Shrubs and Flowers. Elsevier, Boston.

Basset Y, Aberlench HP, Barrios H, Curletti G, Bérenger JM, Vesco JP, Causse P, Haug A, Hennion AS, Lesobre L, Marqués L, Òmeara R. 2001. Stratification and diel activity of arthtropods in a lowland rainforest in Gabon. Biol. J Linn Soc Lond 72: 585-607. DOI: 10.1006/bij1.2001.051

Beaver RA. 2005. A remarkable new species of Cyclorhipidion hagedorn, and new records of bark and ambrosia beetles from Gabon (Coleoptera: Curculionidae: Scolytina, and Platypdinae). Entomol Mon Mag 141:113-119.

Beaver RA. 2013. The intensive neotropical ambrosia beetle Euplatypus parallelus (Fabricius, 1801) in the oriental region and its pest status (Coleoptera: Curculionidae, Plathypodinae). Entomol Mon Mag 149: 143-154.

Beaver RA, Sittichaya W, Liu LY. 2014. A synopsis of Scolytidae ambrosia beetle of Thailand (Coleoptera: Curculionidae: Scolytinae). Zootaxa 3875: 001-082. DOI: 10.11646/zootaxa.3875.1.1

Beaver RA. 2016. The Platypodinae ambrosia beetles of Laos (Coleoptera: Curculionidae: Platypodinae). Entomologica Basiliensia et Collections Frey 35: 487-504.

Bellamy CL, Williams GA, Hasenpusch J, Sundholm A. 2013. A summary of the published data on host plant and morphology of immature stages of Australian jewel beetles (Coleoptera: Buprestidae), with additional new records. Insecta Mundi 0293: 1172.

Beutel RG, Leschen RAB. 2005. Phylogenetic analysis of Staphyliniformia (Coleoptera) based on characters of larvae and adults. Syst. Entomol.30: 510-548. DOI: $10.1111 / \mathrm{j} .1365$ 3113.2005.00293x

Borror DJ, Triplehorn CA, Johnson NF. 1992. Pengenalan Pelajaran Serangga. Penerjemah: Partosoedjono S. Edisi keenam. Gadjah Mada University Press. Yogyakarta

Brar GS, Capinera JL, Kendra PE, McLean S, Peña JE. 2013. Lief cycle, development, and culture of Xyleborus glabratus (Coleoptera: Curculionidae: Scolytinae). Fla Entomol 96: 1158-1167. DOI: 10.1653/024.096.0357
Browne FG. 1961. The biology of Malaya Scolytidae and Platypodidae. Malyan Forest Records 22: 1- 255

Browne FG. 1968. Pest and Diseases of Forest Plantation Trees. Clarendon Press. Oxford.

Brygadyrenko VV, Nazimov SS. 2015. Trophic relations of Opatrum sabulosum (Coleoptera, Tenebrionidae) with leaves of cultivated and uncultivated species of herbaceous plants under laboratory conditions. ZooKeys 481: 57-68. doi: 10.3897/zookeys.481.7015

Bumrungsri S, Beaver RA, Phongpaichit S, Sittichaya W. 2008. The infestation by an exotic ambrosia beetle, Euplatypus parallelus (F.) (Coleoptera: Curculionidae: Platypodinae) of angsana trees (Pterocarpus indicus Willd.) in Southern Thailand. J Sci Technol 30: 579-582.

Coulson RN, Witter JA. 1984. Forest Entomology: Ecology and Management. John Wiley and Sons, Inc. New York.

Duan JJ, Bauer LS, Driesche RGV. 2017. Emerald ash borer biocontrol in ash saplings: the potential for early-stage recovery of North American ash trees. For Ecol Manag 394: 64-72. DOI: 10.1016/j.foreco.2017.03.024

Firdara EK, Mardji D, Simarangkir BDAS. 2009. Identifikasi jenis penyakit pada lima jenis Diptercarpaceae di Kalampangan Zone Kalimantan Tengah. JKTH 2: 29-42. [Indonesian]

Flechtmann CAH, Ottati ALT, Berisford CW. 2001. Ambrosia and bark beetle (Scolytidae: Coleoptera) in pine and eucalypt stand in Southern Brazil. For Ecol Manag 142: 183-191.

Freeman S, Miller G, Protasov A, Maymon M, Elazar M, Schwartz RD, Zhou J, Mendel Z. 2019. Aposymbiotic interactions of three ambrosia beetle fungi with avocado trees. Fungal Ecology 39: 117-130. DOI: 10.1016/j.funeco.2018.11.007

French JRJ, Roeper RA. 1975. Studies on the biology of the ambrosia beetle Xyleborus dispar (F.) (Coleoptera: Scolytidae). Zeitschrift für Angewandte Entomologie 78 (1-4): 241-247.

Fullard JH, Barclay RMR, Thomas DW. 2010. Observations on the behavioural ecology of the Atiu swiftlet Aerodramus sawtelli. Bord Conserv Int120: 385-391. DOI: 10.1017/S095927091000016X

Gibb T. 2015. Contemporary Insect Diagnostics: The Art and Science of Practical Entomology. Elsevier, Oxford.

Gitau CW, Bashford R, Carnegie AJ, Gurr GM. 2013. A review of semiochemicals associated with bark beetle (Coleoptera: Curculionidae: Scolytinae) pest of coniferous trees: a focus on beetle interactions with other pests and their associates. For Ecol Manag 297: 1-14. DOI: $10.1016 /$ j.foreco.2013.02.019 
Gümüs EM, Ergün. 2015. Report of a pest risk analysis for Platypus parallelus (Fabricus, 1801) for Turkey. Eppo bulletin 45: 112-118. DOI: $10.1111 /$ epp. 12190

Gohli J, Selavarajah T, Kirkendall LR, Jordal BH. 2016. Globally distributed Xyleborus species reveal recurrent intercontinental dispersal in a landscape of ancient worldwide distributions. BMC Evolutionary Biology 16: 1-12. DOI: 10.1186/s12862-016-0610-7

Grousset F, Grégoire JC, Jactel H, Battisti A, Beloglavec AB, Hrašovec B, Hulcr J, Daegan I, Orlinski A, Petter F. 2020. The risk of bark and ambrosia beetle associated with imported non-coniferous wood and potential horizontal phytosanitary measures. Forest 11: 1-17. doi:10.3390/f11030342

Harrington TC, Yun HY, Goto H, Aghayeva DN, Fraedrich SW. 2011. Isolations from the readbay ambrosia beetle, Xyleborus glabratus, confirm that the laurel wilt pathogen, Raffaelea lauricola, originated in Asia. Mycologia 103: 1028-1036. DOI: 10.3852/10-417

Huda AN, Salmah MRC, Hamdan A, Razak MNA. 2019. First report of a snout weevil Alcidodes sp. (Coleoptera: Curculionidae) field infestation on mango Mangifera indica L. (Anacardiaceae) in Perlis, Malaysia. Serangga 24: 11-16.

Husaeni EA, Kasno, Haneda NF, Rachmatsjah O. 2006. Pengantar Hama Hutan di Indonesia: Bio-ekologi dan Teknik Pengendalian. Departemen Silvikultur, Fakultas Kehutanan, Institut Pertanian Bogor, Bogor. [Indonesian]

Hwayyiz D, Adam NA, Lau WH. Hazmi I. 2016. Distribution of darkling beetles (Tenebrionidae) in Malaysia. JEZS 4: 1113-1117.

Jha LK, Sen-Sarma PK. (eds.). 2008. Forest Entomology. APH Publishing Corporation, New Delhi.

Junaedi A. 2012. Pertumbuhan dan mutu fisik bibit merawan (Hopea odorata Roxb.) asal sistem koffco di polibag dan potray. Jurnal Penelitian Ekosistem Dipterokarpa 6: 41-50. [Indonesian]

Kalshoven LGE. 1981. The Pest of Crops in Indonesia. PT. Ichtiar BaruVan Hoeve, Jakarta. [Indonesian]

Kangkamanee T, Sittichaya W, Ngampongsai A, Permkam S, Beaver RA. 2011. Wood-boring beetles (Coleoptera: Bostrichidae, Curculionidae, Platypodinae, and Scolytinae) infesting rubberwood sawn timber in Southern Thailand. J For Res 16: 302-308. DOI: 10.1007/s10310010-0224-7.

Kärvemo S, Rogell B, Schroeder M. 2014. Dynamics of spruce bark beetle infestation spots: importance of local population size and landscape characteristics after a storm disturbance. For Ecol Manag 334: 232-240. DOI: 10.1016/j.foreco.2014.09.011

Kirkendall LR, Biedermann PHW, Jordal BH. 2015. Evolution and Diversity of Bark and Ambrosia Beetles Chapter 3. Elsevier, USA. DOI: 10.1016/B978-0-12-417156-5.00003-4

Lei G, Fu Y, Wu W. 2020. Fine structure of mouthparts and forelegs of Euplatypus parallelus (Coleoptera: Curculionidae) with emphasis on the behavior of gallery excavation. Micron 130: 1-14. DOI: 10.1016/j.micron.2019.102815

McPherson BA, Erbilgin N, Bonello P, Wood DL. 2013. Fungal species assemblages associated with Phytophthora ramorum-infected coast live oaks following bark and ambrosia beetle colonization in Northern California. For Ecol Manag 291: 30-42. DOI: 10.1016/j.foreco.2012.11.010

Misra KG, Singh V, Yadava AK, Misra S, Yadav R. 2020. In vitro rearing and gallery tunneling pattern of island pinhole borer, Xyleborus perforans (Wollaston), a scolytid associated with pomegranate with complex. Curr Sci 118: 195-198.

Oberprieler RG, Marvaldi AE, Anderson RS. 2007. Weevils, weevils, weevils everywhere. Zootaxa 1668: 491-520

O’Donnell K, Sink S, Hadas RL, Hulcr J, Kasson MT, Ploetz RC, Konkol JL, Ploetz JN, Carillo D, Campbell A, Duncan RE, Liyanage NH, Eskalen A, Na F, Geiser DM, Bateman C, Freeman S, Mendel Z, Sharon M, Aoki T, Cossé AA, Rooney AP. 2014. Discordant phylogenies suggest repeated host shifts in Fusarium-Euwallacea ambrosia beetle mutualism. Fungal Genet Biol. 82: 277-290. DOI: 10.1016/j.fgb.2014.10.014.

Pineda SV, Jones RW, Sandoval VHC, Zúńiga JAO, Martìnez AE. 2014. Bark beetle species (Coleoptera: Curculionidae: Scolytinae) and their vertical distribution on Pinus greggii during an outbreak in the Siera Madre Oriental of Mexico. Southwest Entomol 39: 193-196. DOI: 10.3958/059.039.0122

Ploetz RC, Hulcr J, Wingfield MJ, Beer ZWD. 2013. Destructive tree diseases associated with ambrosia and bark beetles: black swan events in tree phatology?. Plant Dis. 95: 856-87. DOI: 10.1094/PDIS-01-130056-FE

Pracaya. 2007. Hama dan Penyakit Tanaman. Penerbit Swadaya. Jakarta

Ramasamy M. 2018. A scientific note on occurrence and infestation of jewel beetle Belionata prasina (Coleoptera: Buprestidae) on chasew (Anacardium occidentale). Natl Acad Sci Let 42: 91-94. DOI: 10.1007/s40009-018-0706-2

Rassati D, Faccoli M, Haack RA, Rabaglia J, Toffolo EP, Battisti A, Marini L. 2016. Bark and ambrosia beetle show different invansion patterns in the USA. PLoS ONE 11: 1-17. DOI: 10.1371/journal.pone.0158519.

Ruano F, Campos M, Raya AJS, Peña A. 2010. Olive trees protected from the olive bark beetle, Phloeotribus scarabaeoides (Bernard 1788) (Coleoptera, Curculionidae, Scolytinae) with a pyrethroid insecticide: effect on the insect community of the olive grove. Chemosphere 80 : 35-40. doi:10.1016/j.chemosphere.2010.03.039.

Saengyot S. 2016. Predatory thrips species composition their prey and host plant association in Northern Thailand. Agric Nat Resour 50: 380-387. DOI: 10.1016/j.anres.2015.10.002.

Sauvard D, Branco M, Lakatos F, Faccoli M, Kirkendall LR. 2010. Weevils and bark beetles (Coleoptera, Curculionidae) chapter 8.2. Bio Risk 4: 219-266. DOI: 10.3897/biorisk.4.64.

Schnepp KE, Ashman KL, Moore MR. 2020. Report of an established population of Belionota prasina (Thunberg) (Coleoptera: Buprestidae: Buprestinae) in Florida. Coleopt Bull 74: 124-126. DOI.org/10.1649/0010-065X-74.1.124

Sittichaya W, Permkam S, Cognato AI. 2012. Species composition and flight pattern of Xyleborini ambrosia beetles (Col: Curculionidae: Scolytinae) from agricultural areas in Southern Thailand. Ecol Entomol 41: 776-784. DOI: 10.1603/EN11271

Soldati F, Soldati L. 2003. Réactualisation de la liste systématique des celéoptéres Tenebrionidae (Alleculinae exculs) de france continental et de corse. Bull Mens Soc Linn Lyon 72: 331-349. DOI: 10.3406/linly.2003.13495.

Soerianegara I, Lemmens RHMJ. 1994. Plant Resources of South-East Asia: Timber Trees: Major Comercial Timbers. Prosea, Bogor.

Speight MR, Wylie FR. 2000. Insect Pests in Tropical Forestry. CABI Publishing, London.

Tang J, Li J, Lu H, Lu F, Lu B. 2018. Potential distribution of an invasive pest, Euplatypus parallelus, in China as predicted by Maxent. Pest Manag Sci 75: 1630-1637. DOI: 10.1002/ps.5280

Tarno H, Suprapto H, Himawan T. 2014. First record of ambrosia beetle (Euplatypus paralellus Fabricius) infestation on sonokembang (Pterocarpus indicus Willd.) from Malang Indonesia. Agrivita 36: 189-200. DOI: 10.17503/Agrivita-2014-36-2-p189-200

Triwibowo H, Jumani, Emawati H. 2014. Identifikasi hama dan penyakit Shorea leprosula Miq di Taman Nasional Kutai Resort Sangkima Kabupaten Kutai Timur Provinsi Kalimantan Timur. J Agrifor 8: 175184.

Wahyudi A, Sari N, Saridan A, Cahyono DDN, Rayan, Noor M, Fernandes A, Abdurachman, Apriani H, Handayani R, Hardjana AK, Susanty FH, Karmilasanti, Ngatiman, M. Fajri, Wiati CB, Wahyuni T. 2014. Shore Leprosula Miq dan Shorea johorensis Foxw: Ekologi, Silvikultur, Budidaya, dan Pengembangan. Balitbanghut Kaltim, Samarinda. [Indonesian] 